\title{
Impact of Pedagogy Intervention for Reading and Writing Abilities on Pre School Students
}

\author{
Dr Veena Bhalerao ${ }^{1}$ Prof Vishala Patnam ${ }^{2}$
}

\begin{abstract}
The pedagogy intervention for reading and writing abilities brought about significant positive changes to the level of good and very good grades of preschool students in their Marathi alphabet \& numbers and English alphabet \& Arabic numbers as compared to their counterparts in the control group. Irrespective of their groups, the Marathi alphabet \& numbers and English alphabet \& Arabic numbers reading and writing abilities of the preschool students were significantly positively correlated with their intelligence quotient, child friendly environment in the classroom, maternal education, family size \& income and family support extended to the child. The executed pedagogy intervention for reading and writing abilities of pre school students found to have significant impact in enhancing their reading and writing abilities of Marathi alphabet \& numbers and English alphabet \& Arabic numbers in addition to selected pictures reading and its awareness.
\end{abstract}

\section{Introduction}

Children learn about reading from the time they are born, they learn about writing from infancy, as they watch adults and older siblings using writing as means of communication. The word writing and the way they sound actually helps children in beginning reading (Cynthia, 2010).However Kaul et al. (1993) found positive role of ECE in promoting cognitive and social skills and improved participation and learning achievements in primary classes and best advantage of schooling in the initial stages. Extensive research evidence shows the positive impact of early interventions and the long-term effects of early childhood education and links between the educational and care processes on children's development outcomes. Head Start revealed research reported that participation in the programme had a significant short-term positive impact on academic and social development of disadvantaged children (Mc Key et al. 1985; Lazar and Darlington 1982). Children who had attended Head Start showed larger gains on measures of social and cognitive functioning when compared with those who had no pre-school experience. Besides intellectual gains, these children remained in the mainstream education and had a positive view about themselves and their future (Barnett, 1990). ECE Perry Pre-school Project, now known as High/Scope study (Schweinhart etal1993) indicated that children who had attended High/Scope had higher educational attainment reading and writing, higher self esteem and lower anxiety than control group children. In comparison with the conventional nursery group, High/Scope children performed better on academic outcomes and quality of pre-school curriculum have a bearing on the learning.1 Assistant Professor, 2 Professor \& Head (HD\&FS) and Associate Dean \& Principal, College of Home Science Marathwada Krishi Vidyapeeth, Parbhani 431402

Keeping in mind the importance of introducing pre reading and writing to preschoolers, a research was conducted with objective of studying impact of executing and assessing need based pedagogy intervention on the reading and writing abilities for the sample pre school students in both the control and experimental groups.

\section{Methodology}

The study was carried out on 87 preschool students (4-5 yrs old). Out of them 58 students were from Lab Pre Primary School MKV and 29 students from a randomly selected local preschool. The LPP school students were given planned pedagogy intervention for reading and writing abilities based on scientific, well proven methods and techniques in child education. This type of input was given as this group was considered as the experimental group. On the other hand, the local private preschool students (29) were exposed to conventional pedagogy methods and techniques, as this preschool was considered as the control group. The preschool curriculum of the control and experimental groups' was same for the period of 9 months except the adopted teaching methods and techniques. The major components of curriculum included of reading and writing Marathi alphabet ( A-Dnya, 47 ), Marathi numbers (1-50), complete English alphabet (A-Z, 26), Arabic numbers (1-50), colourful digital pictures related to 4 topics i.e. domestic and wild animals (30), colours (10), shapes (10) and body parts (30). The sample students' reading and writing abilities were assessed by administering the preschool student assessment inventory developed by the investigators for grading their selected abilities on the four point scale i.e. very good, good, fair and poor. These grades were assigned the scores of 4, 3, 2 and 1 respectively. To study the impact of pedagogy of intervention for reading and writing abilities, the pre and post tests' grading of the students in the control and experimental groups were compared. 
The recorded reading and writing abilities of the students were correlated with their selected personal and parental variables for identifying the influencing factors on these abilities of preschool students. The growth quotient (GQ) of these students was assessed by taking their anthropometric measurements as per the standard procedures. Their intelligence quotient (IQ) was assessed by administering two IQ tests i.e. Seguin form board test and modified RCPM test. The collected data was pooled and statistically analyzed.

III. Findings

Majority of the preschool students were either first or middle born in the control and experimental groups. The sample was comprised of 41-55 per cent boys and the remaining were girls. Thirty four to 38 per cent preschool students assessed to have below average intelligence while the remaining was found to have average (32-37\%) and above average intelligence (24-31 \%). Thirty one to 43 per cent of the preschoolers found to have good growth quotient (GQ) while the remaining were found to have very good growth (GQ).

Table 2 illustrates the pedagogy intervention for Marathi alphabet \& numbers and English alphabet \& Arabic numbers reading. It was found that this intervention has brought about significant positive changes to the level of good and very good grades in a higher percentage (24-41\%) of preschoolers. On the other hand in the control group, a higher percentage (13-55\%) of the preschool students who were exposed to the conventional methods of teaching and techniques for reading Marathi alphabet \& numbers and English alphabet \& Arabic numbers, improved to the fair and good grades. However the reading ability outcome of these students through such conventional method found to be non significant even after receiving training for 9 months period, while the experimental group students' reading ability outcome found to be extraordinary as compared to their counterparts in the control group.

Similarly Sakamoto (1975) stated that Japanese parents read many picture books to their children and it resulted in highly regular phonetic writing of these children. It evidenced that letter writing ability of these children was based more on mode of spelling knowledge than a pure motoric ability and this linguistic skill influenced spelling outcomes of children.

Table 3 details the pedagogy intervention of writing Marathi alphabet \& numbers and English alphabet \& Arabic numbers brought about significant positive changes in 30-54 per cent preschool students to the level of good and very good grades in it. On the other hand in the control group , 10 - 62 per cent preschool students who were exposed to conventional methods of teaching and techniques for writing Marathi alphabet \& numbers and English alphabet \& Arabic numbers, improved it to fair and good grades. However the writing ability outcome of these students through such conventional method found to be non significant even after receiving training for 9 months period. The experimental group students' writing ability of Marathi alphabet \& numbers outcome found to be extraordinary as compared to their counterparts in the control group.

The pedagogy intervention for picture reading of animals, colours, shapes, body parts and awareness brought significant positive changes in 18-63 per cent experimental group preschool students to the level of good and very good grades in it.

Laura etal (2005) studied 106 disadvantaged preschool children attending 23 classrooms serving for 30 weeks period wherein 14 classrooms used a print referencing style of story book reading while in 9 classrooms were considered as control group who were exposed to routine reading methods. The research showed larger gains on 3 standardized measures of print knowledge, alphabet and writing name when compared to control group preschoolers. The evidence based technique of teaching pupil in the classroom with use of print reference style was found to be more effective.

Table 5 shows that irrespective of their groups, the Marathi alphabet \& numbers and English alphabet $\&$ Arabic numbers reading abilities of the preschool students were significantly positively correlated with their intelligence quotient, child friendly environment in the classroom, maternal education, family size \& income and family support extended to the child. Irrespective of the groups of preschool students, the variables like growth quotient, intelligence quotient, child friendly classroom environment, family income, family support extended to child were significantly positively correlated to the preschool students' writing abilities of Marathi alphabet \& numbers and English alphabet \& Arabic numbers.

\section{Conclusion}

The executed pedagogy intervention for reading and writing abilities of pre school students found to have significant impact in enhancing their reading and writing abilities of Marathi alphabet $\&$ numbers and English alphabet \& Arabic numbers in addition to selected pictures reading and its awareness. 
Table 1 Background variables of pre school students

\begin{tabular}{|c|c|c|c|c|}
\hline Background variables & \multicolumn{3}{|c|}{ Percentage of preschool students } & $Z$ values \\
\hline \multicolumn{5}{|l|}{ Gender } \\
\hline Male & 55.17 & \multicolumn{2}{|c|}{41.37} & $1.24^{\mathrm{NS}}$ \\
\hline Female & 44.82 & \multicolumn{2}{|c|}{58.62} & $1.24^{\mathrm{NS}}$ \\
\hline \multicolumn{5}{|l|}{ Ordinal position } \\
\hline First & 34.48 & \multicolumn{2}{|c|}{63.79} & $2.67 * *$ \\
\hline Middle & \multirow{2}{*}{$\frac{44.82}{20.68}$} & \multicolumn{2}{|c|}{3.44} & $4.32 * *$ \\
\hline Last & & \multicolumn{2}{|c|}{32.75} & $1.24^{\mathrm{NS}}$ \\
\hline \multicolumn{4}{|l|}{$\begin{array}{l}\text { Intelligence quotient \& } \\
\text { categories }\end{array}$} & \\
\hline 91-100 Below Average & 37.93 & \multicolumn{2}{|c|}{34.48} & $0.27^{\mathrm{NS}}$ \\
\hline 101-110 Average & \multirow{2}{*}{$\begin{array}{ll}37.93 \\
24.13\end{array}$} & \multicolumn{2}{|c|}{32.75} & $0.46^{\mathrm{NS}}$ \\
\hline 111-140 Above average & & \multicolumn{2}{|c|}{31.86} & $0.10^{\mathrm{NS}}$ \\
\hline \multicolumn{4}{|l|}{ Growth quotient \& categories } & \\
\hline$>85 \quad$ Good & \multirow{2}{*}{$\begin{array}{l}31.03 \\
68.96\end{array}$} & \multicolumn{2}{|c|}{43.10} & $1.11^{\mathrm{NS}}$ \\
\hline$>90 \quad$ V. Good & & \multicolumn{2}{|c|}{56.89} & $1.0^{\mathrm{NS}}$ \\
\hline Type of Family & 68.96 & & & \\
\hline Nuclear & 65.51 & & & $1.72^{\mathrm{NS}}$ \\
\hline Joint & 17.24 & & & $3.23 * *$ \\
\hline Extended & 17.24 & & & $1.59^{\mathrm{NS}}$ \\
\hline Size of Family & & & & \\
\hline Small (Be lows) & 51.72 & & & $0.44^{\mathrm{NS}}$ \\
\hline Medium ( 6-8) & 34.48 & & & $1.27^{\mathrm{NS}}$ \\
\hline Large (above 8) & 13.79 & & & $1.16^{\mathrm{NS}}$ \\
\hline Monthly family income & & & & \\
\hline Below 10,000 & 48.27 & & & $0.79^{\mathrm{NS}}$ \\
\hline $10,000-35000$ & 44.82 & & & $0.61^{\mathrm{NS}}$ \\
\hline $35,000-50,000$ & 6.89 & & & $0.35^{\mathrm{NS}}$ \\
\hline Edu. level of parents & $\begin{array}{c}\text { Mothers } \\
\text { (29) (b) }\end{array}$ & $\begin{array}{c}\text { Fathers } \\
(57)(c)\end{array}$ & \begin{tabular}{|c|} 
Mother \\
s (58) \\
(d) \\
\end{tabular} & aVsc bVs d \\
\hline School educated & 37.93 & 24.56 & 55.17 & $2.86 * 4 * 25 * *$ \\
\hline Graduates & 44.82 & 43.58 & 34.48 & $0.82^{\mathrm{NS}}$ \\
\hline Post graduates & 4.72 & 31.57 & 10.34 & $4.72 * * 1.66^{\mathrm{NS}}$ \\
\hline Occupation of parents & & & & \\
\hline Home makers & 86.20 & - & 84.48 & - \\
\hline Employed & 55.17 & 63.15 & 12.06 & $5.82 * * 4.64 * *$ \\
\hline Business & 44.82 & 36.84 & 3.44 & $4.67 * * \quad-$ \\
\hline
\end{tabular}

NS - Non Significant $*$ - significant at $\mathrm{P}<0.05$ level $\quad * *$ - significant at $\mathrm{P}<0.01$ level

Table 2 Comparison between reading ability grades of preschool students of the control and experimental groups

\begin{tabular}{|c|c|c|c|c|c|c|c|c|}
\hline \multirow{3}{*}{$\begin{array}{c}\text { Reading of } \\
\text { students and its } \\
\text { grading }\end{array}$} & \multicolumn{6}{|c|}{ Percentages of preschool students } & \multirow{2}{*}{\multicolumn{2}{|c|}{$Z$ values }} \\
\hline & \multicolumn{2}{|c|}{ group } & $\begin{array}{l}\text { Control } \\
\qquad(\mathrm{n}-29) \\
\end{array}$ & \multicolumn{3}{|c|}{$\begin{array}{c}\text { Experimental group } \\
(\mathbf{n}-58)\end{array}$} & & \\
\hline & $\begin{array}{r}\text { Pre } \\
\text { test } \\
\text { (a) }\end{array}$ & $\begin{array}{l}\text { Post test } \\
\text { (b) }\end{array}$ & $\begin{array}{c}\mathbf{Z} \\
\text { value } \\
\mathbf{s} \\
\mathbf{a V s} \mathbf{b}\end{array}$ & $\begin{array}{l}\text { Pre test } \\
\text { (c) }\end{array}$ & $\begin{array}{l}\text { Post } \\
\text { test } \\
\text { (d) }\end{array}$ & $\begin{array}{c}\mathrm{Z} \\
\text { values } \\
\text { c Vs } \\
\text { d }\end{array}$ & a Vs c & bVs d \\
\hline Marathi alphabet & & & & & & & & \\
\hline Very good & $\begin{array}{c}10.3 \\
4\end{array}$ & 17.24 & $\underset{\mathrm{NS}}{\mathbf{0 . 7 8}}$ & 5.17 & 41.03 & $5.09 * *$ & $3.63 * *$ & $2.52 *$ \\
\hline Good & $\begin{array}{c}24.1 \\
3\end{array}$ & 41.37 & $\underset{\mathrm{NS}}{1.40}$ & 15.51 & 36.20 & $2.67 * *$ & $1.18^{\mathrm{NS}}$ & $0.45^{\mathrm{NS}}$ \\
\hline Fair & $\begin{array}{c}31.0 \\
3\end{array}$ & 27.58 & $\underset{\text { NS }}{0.33}$ & 29.31 & 18.13 & $1.40^{\mathrm{NS}}$ & $1.30^{\mathrm{NS}}$ & $0.933^{\mathrm{NS}}$ \\
\hline Poor & $\begin{array}{c}34.4 \\
8\end{array}$ & 13.79 & $\underset{\text { NS }}{1.94}$ & 50 & 4.62 & $6.52 * *$ & $3.27 * *$ & $1.33^{\mathrm{NS}}$ \\
\hline
\end{tabular}


Impact Of Pedagogy Intervention For Reading And Writing Abilities On Pre School Students

\begin{tabular}{|c|c|c|c|c|c|c|c|c|}
\hline \multicolumn{9}{|c|}{ Marathi numbers } \\
\hline Very good & 6.89 & 13.79 & $\underset{\text { NS }}{0.91}$ & 10.34 & 38.96 & $3.73 * *$ & $4.12^{* *}$ & $2.80 * *$ \\
\hline Good & $\begin{array}{c}10.3 \\
4\end{array}$ & 20.68 & $\underset{\mathrm{NS}}{1.00}$ & 29.31 & 32.75 & $0.35^{\mathrm{NS}}$ & $2.65^{* *}$ & $1.24^{\mathrm{NS}}$ \\
\hline Fair & $\begin{array}{c}31.0 \\
3\end{array}$ & 44.82 & $\underset{\text { NS }}{1.00}$ & 27.58 & 21.37 & $0.75^{\mathrm{NS}}$ & $0.98^{\mathrm{NS}}$ & $2.15 *$ \\
\hline Poor & $\begin{array}{c}51.7 \\
2\end{array}$ & 20.68 & $2.60 *$ & 32.75 & 6.89 & $3.78 * *$ & $4.59^{* *}$ & $1.74^{\mathrm{NS}}$ \\
\hline \multicolumn{9}{|c|}{ English alphabet } \\
\hline Very good & 6.89 & 10.34 & $\underset{\text { NS }}{0.56}$ & 12.06 & 40.51 & $3.62 * *$ & $4.35^{\mathrm{NS}}$ & $3.52 * *$ \\
\hline Good & $\begin{array}{c}20.6 \\
8\end{array}$ & 13.79 & $\underset{\mathrm{NS}}{\mathbf{0 . 7 2}}$ & 34.48 & 32.75 & $0.22^{\mathrm{NS}}$ & $1.24^{\mathrm{NS}}$ & $2.17 *$ \\
\hline Fair & $\begin{array}{c}34.4 \\
8 \\
\end{array}$ & 55.17 & $\underset{\mathrm{NS}}{1.64}$ & 15.51 & 16.20 & $0.14^{\mathrm{NS}}$ & $1.79^{\mathrm{NS}}$ & $3.74 * *$ \\
\hline Poor & $\begin{array}{c}37.9 \\
3 \\
\end{array}$ & 20.68 & 1.46 & 37.93 & 10.51 & $3.61 * *$ & $2.75^{\mathrm{NS}}$ & $1.18^{\mathrm{NS}}$ \\
\hline \multicolumn{9}{|c|}{ Arabic numbers } \\
\hline Very good & $\begin{array}{c}13.7 \\
9\end{array}$ & 17.24 & $\underset{\mathrm{NS}}{\mathbf{0 . 4 2}}$ & 18.96 & 34.13 & $1.99^{*}$ & $2.38 *$ & $1.81^{\mathrm{NS}}$ \\
\hline Good & $\begin{array}{c}13.7 \\
9 \\
\end{array}$ & 27.58 & $\underset{\mathrm{NS}}{1.35}$ & 24.13 & 24.13 & - & $1.31^{\mathrm{NS}}$ & $0.300^{\mathrm{NS}}$ \\
\hline Fair & $\begin{array}{c}41.3 \\
7 \\
\end{array}$ & 37.93 & $\begin{array}{c}\mathbf{0 . 3 1} \\
\text { NS }\end{array}$ & 25.86 & 26.20 & $0.12^{\mathrm{NS}}$ & $1.38^{\mathrm{NS}}$ & $1.033^{\mathrm{NS}}$ \\
\hline Poor & $\begin{array}{c}31.0 \\
3\end{array}$ & 17.24 & 1.26 & 31.03 & 15.51 & $2.08 *$ & $1.68^{\mathrm{NS}}$ & $0.23^{\mathrm{NS}}$ \\
\hline
\end{tabular}

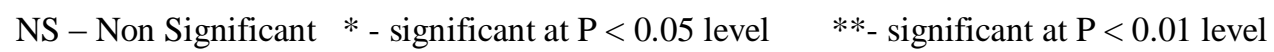

Table 3 Comparison between writing ability grades of pre school students of the control and experimental groups

\begin{tabular}{|c|c|c|c|c|c|c|c|c|}
\hline \multirow[b]{3}{*}{$\begin{array}{c}\text { Writing of } \\
\text { students and its } \\
\text { grading }\end{array}$} & \multicolumn{6}{|c|}{ Percentages of preschool students } & \multirow{2}{*}{\multicolumn{2}{|c|}{$Z$ values }} \\
\hline & \multicolumn{3}{|c|}{ Control group (n-29) } & \multicolumn{3}{|c|}{ Experimental group (n-58) } & & \\
\hline & $\begin{array}{l}\text { Pre test } \\
\text { (a) }\end{array}$ & $\begin{array}{l}\text { Post test } \\
\text { (b) }\end{array}$ & $\begin{array}{c}\mathrm{Z} \text { values } \\
\text { aVs b }\end{array}$ & $\begin{array}{l}\text { Pre test } \\
\text { (c) }\end{array}$ & $\begin{array}{l}\text { Post test } \\
\text { (d) }\end{array}$ & $\begin{array}{l}\text { Z values } \\
\text { c Vs } \\
\text { d }\end{array}$ & a Vs c & bVs d \\
\hline \multicolumn{9}{|l|}{$\begin{array}{l}\text { Marathi } \\
\text { alphabet }\end{array}$} \\
\hline Good & 17.24 & 31.03 & $1.26^{\mathrm{NS}}$ & 17.24 & 54.31 & $4.51 * *$ & - & $2.13 *$ \\
\hline Fair & 31.03 & 27.58 & $0.33^{\mathrm{NS}}$ & 18.96 & 8.96 & $1.61^{\mathrm{NS}}$ & $1.30^{\mathrm{NS}}$ & $2.11 *$ \\
\hline Poor & 37.93 & 13.79 & $2.19 * *$ & 53.44 & 5.34 & $6.71 * *$ & $1.44^{\mathrm{NS}}$ & $1.16^{\mathrm{NS}}$ \\
\hline \multicolumn{9}{|l|}{$\begin{array}{l}\text { Marathi } \\
\text { numbers }\end{array}$} \\
\hline Poor & 24.13 & 6.89 & $1.98^{\mathrm{NS}}$ & 37.93 & 5.17 & $4.60 * *$ & $1.28^{\mathrm{NS}}$ & $0.19^{\mathrm{NS}}$ \\
\hline \multicolumn{9}{|l|}{ English alphabet } \\
\hline Very good & 17.24 & 44.82 & $2.33 *$ & 8.62 & 47.58 & $5.22 * *$ & $1.14^{\mathrm{NS}}$ & $0.25^{\mathrm{NS}}$ \\
\hline Good & 27.58 & 34.48 & $0.58^{\mathrm{NS}}$ & 12.06 & 41.72 & $3.74 * *$ & $1.61^{\mathrm{NS}}$ & $0.64^{\mathrm{NS}}$ \\
\hline Fair & 24.13 & 13.79 & $1.08^{\mathrm{NS}}$ & 32.75 & 7.24 & $3.58 * *$ & $0.79^{\mathrm{NS}}$ & $0.84^{\mathrm{NS}}$ \\
\hline Poor & 31.03 & 6.89 & $2.58 *$ & 46.55 & 3.44 & $6.21 * *$ & $1.38^{\mathrm{NS}}$ & $0.066^{\mathrm{NS}}$ \\
\hline \multicolumn{9}{|l|}{ Arabic numbers } \\
\hline Very good & 6.89 & 37.98 & $3.10 * *$ & 12.06 & 47.75 & $4.47 * *$ & $0.97^{\mathrm{NS}}$ & $0.90^{\mathrm{NS}}$ \\
\hline Good & 13.79 & 44.82 & $2.78 * *$ & 15.51 & 40.00 & $3.14 * *$ & $0.25^{\mathrm{NS}}$ & $0.35^{\mathrm{NS}}$ \\
\hline
\end{tabular}


Table 4 Comparison between picture reading ability and awareness grades of preschool students of the control and experimental groups

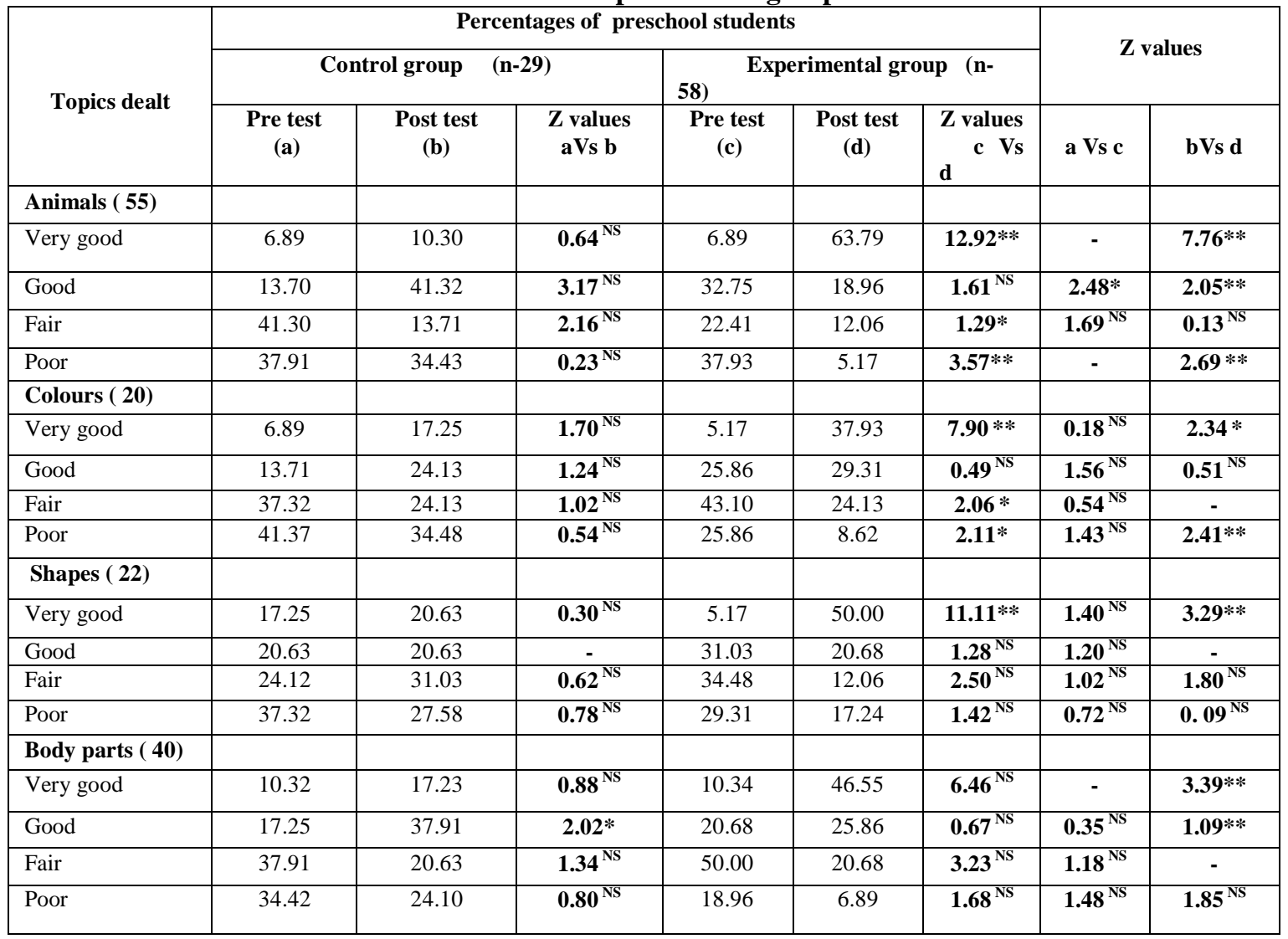

NS - Non Significant * - significant at $\mathrm{P}<0.05$ level $* *$ - significant at $\mathrm{P}<0.011$

The numbers in the parenthesis of the first column indicate the number of questions asked to the students on that topic.

Table 5 Correlation between reading and writing abilities of the control and experimental group preschool students and their selected background

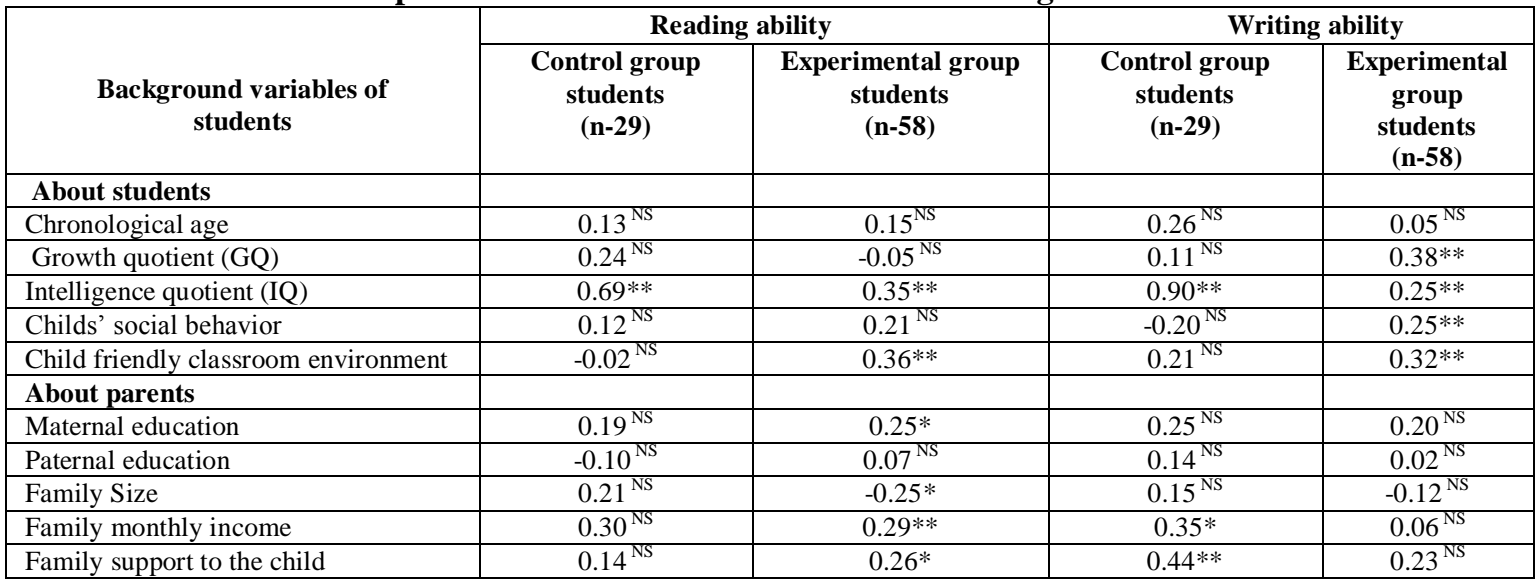

$$
\text { NS - Non significant } * \text { - significant at } \mathrm{P}<0.05 \text { level } \quad * * \text { - significant at } \mathrm{P}<0.01 \text { level }
$$




\section{References}

[1]. Barnett (1990) School based prevention programmes for children and adolescents, Sage publications, London, UK

[2]. Cynthia Puranik (2010) Effect of assessment task and letter writing ability on preschool children's spelling performance, cited on http://www.pbs.org/parents/readinglanguage/ writing/main.html

[3]. Kaul Venitha et al. (1993) Impact of early childhood education on retention in primary grades -A longitudinal study ,National Council of Educational Research and Training, New Delhi

[4]. Laura J, Joan K, Xitao F, Aileen H. (2005) Accelerating preschooler's early literacy development through classroom based teacher child storybook reading an explicit print referencing.

[5]. Lazar and Darlington( 1982a) Does Head start work?, A 1 yr follow up comparison of disadvantaged children attending head start, No preschool programs, Developmental psychology,24(210-222)

[6]. Mc Key HR; Condelli L; GansonH; BarrettB; Mc Conkey C; Plantz M (1985) The impact of Head start on children, families and communities, The Head Start Bureau, Human Development services, CSR In corporation,Washington DC

[7]. Sakamoto Takahiko (1975) Preschool reading in Japan, Dept. of Reading, Noma institute of educational research, Japan

[8]. Schweinhart L J, Barnes H V, Weikart DP (1993) Significant benefits: The High/ Scope preschool curriculum comparison through age 23,High/ Scope press, Ypsilanti,Michigan 